\title{
Offer and Use of Oral Health in Primary Care Before and After the Beginning of the COVID-19 Pandemic in Brazil
}

Edson Hilan Gomes de Lucena ${ }^{1} \mathbb{0}$, Aldelany Ramalho Freire ${ }^{1}(\mathbb{0})$, Deborah Ellen Wanderley Gomes Freire $^{1} \mathbb{1}$, Elza Cristina Farias de Araújo ${ }^{1}{ }^{\circledR}$, Gabriela Nazaré Wanderley Lira ${ }^{1}{ }^{\circledR}$, Arella Cristina Muniz Brito ${ }^{1}$, Wilton Wilney Nascimento Padilha ${ }^{1}$ (1), Yuri Wanderley Cavalcanti ${ }^{1}$

${ }^{1}$ Department of Clinical and Social Dentistry, School of Dentistry, Federal University of Paraíba, João Pessoa, PB, Brazil.

Author to whom correspondence should be addressed: Edson Hilan Gomes de Lucena, Departamento de Clínica e Odontologia Social, DCOS/CCS/UFPB, Universidade Federal da Paraíba, Cidade Universitária, Campus I João Pessoa, PB, Brazil. 58051-900. E-mail: edson.lucena@,academico.ufpb.br

Academic Editor: Alessandro Leite Cavalcanti

Received: 19 June 2020 / Review: 13 July 2020 / Accepted: 24 July 2020

How to cite this article: Lucena EHG, Freire AR, Freire DEWG, Araújo ECF, Lira GNW, Brito ACM, et al. Offer and use of oral health in primary care before and after the beginning of the COVID-19 pandemic in Brazil. Pesqui Bras Odontopediatria Clín Integr. 2020; 20(supp1):e0139. https://doi.org/10.1590/pboci.2020.163

\begin{abstract}
Objective: To compare the offer and use of oral health services in primary care, before and after the beginning of the COVID-19 pandemic in Brazil. Material and Methods: An observational study with a cross-sectional ecological design, using data from the Health Information System for Primary Care. Data regarding the number of Oral Health Teams (OHT), Oral Health Coverage in Primary Care (OHC), number of First Programmatic Dental Consultations (FPDC), and number of visits due to dental abscess and toothache were collected. Data regarding the 26 Brazilian states and Federal District were collected, as consolidated of the first quarter (January to April) of 2019 and of 2020. The median of the difference (MD) and the percentage of variation $(\% \mathrm{~V})$ were obtained for each variable and were compared by Wilcoxon test $(\alpha<0.05)$. Results: An increase in the number of OHT was observed in 25 states $(\mathrm{MD}=45 ; \% \mathrm{~V}=6.13$; $\mathrm{p}<0.001)$, whilst the OHC increased in 17 states $(\mathrm{MD}=1.01 ; \% \mathrm{~V}=1.62 ; \mathrm{p}=0.035)$ between the 2019 and 2020. We also verified a significant reduction in the number of $\mathrm{FPDC}(\mathrm{MD}=-42.806$; \% $\mathrm{V}=-38.70 ; \mathrm{p}<0.001)$, as well as in the number of visits due to dental abscess (MD=-1.032; \%V=-29.04; $\mathrm{p}=0.002)$ and due to toothache $(\mathrm{MD}=-14.445 ; \% \mathrm{~V}=-32.68 ; \mathrm{p}<0.001)$. Conclusion: Although an expansion of OHT and OHC between 2019 and 2020 was verified, the offer and use of oral health services in primary care has decreased due to the COVID-19 pandemic.
\end{abstract}

Keywords: COVID-19; Oral Health; Primary Health Care; Health Services Accessibility. 


\section{Introduction}

The first cases of COVID-19, a respiratory infection caused by the new coronavirus (SARS-CoV-2), were reported on December 29, 2019, in the Wuhan province, China. The rapid and exponential increase in the number of cases of the disease indicates that COVID-19 is more contagious than previous epidemics such as Severe Acute Respiratory Syndrome (SARS-CoV) and Middle East Respiratory Syndrome (MERS-CoV), which makes it more lethal in absolute numbers. After its discovery, the virus spread rapidly throughout the world, and on March 11th, 2020, the World Health Organization (WHO) declared the COVID-19 pandemic $[1-3]$.

In Brazil, the first case was confirmed on February 25th, 2020, being the first country to report a COVID-19 case in Latin America. On March 20th, 2020, the country acknowledged the occurrence of community transmission of the disease, and from then on, the Ministry of Health recommended measures of social isolation for the entire population [4-7].

Social isolation measures are indicated in cases where it is no longer possible to identify all of those who were infected or their contacts in time to delay the spread of the disease [8]. This type of intervention involves social distancing measures, such as closing schools and canceling public events, to completely blocking activities in a city [7,9].

However, Brazil is currently considered the center of the epidemic, which can be attributed to the fact that official government communication has not fully adhered to a series of isolation measures recommended by WHO [10). The government chose to invest mainly in the hospital network, neglecting the strengthening of primary health care, which may favor the collapse of the health system before the increasing trend of COVID-19 cases [11].

The changes in the country's epidemiological scenario during the COVID-19 pandemic affected not only professionals who provide direct health assistance related to this disease, but other health professionals and the population that uses this service. For dental care, according to the Technical Note No. 9/2020, the main orientation of the Ministry of Health is to suspend elective care, maintaining emergency cases that must be performed individually to prevent the spread of the virus [12]. Such measures taken to protect professionals and users of health services will also impact the indicators of these services, such as access and resolution indicators, in addition to contributing to an increase in the restrained demand.

The frequency of dental care records within the e-SUS APS individual dental care form can identify the impact that the COVID-19 pandemic can have on the offer of oral health services and indicators in Brazil [13]. The e-SUS APS individual dental care form includes the registration of the First Programmatic Dental Consultation (PCOP) and Emergency Care. These parameters can then be used as indicators of the population's access to oral healthcare services. Given the above, this study aimed to compare the offer and use of oral health services in primary care of the Brazilian National Health System (SUS), before and after the beginning of the COVID-19 pandemic in Brazil.

\section{Material and Methods}

Study Design 
This is an observational, descriptive, and analytical study, with a cross-sectional ecological design, which used data from public reports of the Health Information System for Primary Care (SISAB) of the Ministry of Health of Brazil (https://egestorab.saude.gov.br/paginas/acessoPublico/relatorios/ relatoriosPublicos.xhtml).

\section{Data Collection}

Data regarding the number of Oral Health Teams (OHT), Oral Health Coverage in Primary Care (OHC), number of First Programmatic Dental Consultations (FPDC), and number of visits due to dental abscess and toothache were collected in the 26 Brazilian states and Federal District. Data were collected and analyzed as consolidated of the first four months (January to April) of 2019 and 2020, the period considered before and after, respectively, the beginning of the COVID-19 pandemic in Brazil. Data were collected on 15th of June 2020.

\section{Data Analysis}

Initially, for each study variable, the median difference (MD) and the percentage of variation (\%V) were calculated. Data were then compared using the Wilcoxon non-parametric test, considering the $95 \%$ confidence interval and the $5 \%$ statistical significance. The data were tabulated and analyzed using the Statistical Package for Social Sciences software (IBM-SPSS, v.24, IBM, Chicago, IL, USA).

\section{Results}

The comparative data between the January-April of 2019 and January-April of 2020 are shown in Table 1. An increase in the number of OHT was observed in 25 states $(\mathrm{p}<0.001)$, whilst the OHC increased in 17 states $(\mathrm{p}=0.035)$ between 2019 and 2020 (Table 1). We also verified a reduction in the number of FPDC $(\mathrm{p}<0.001)$, as well as in the number of visits due to dental abscess $(\mathrm{p}=0.002)$ and toothache $(\mathrm{p}<0.001)($ Table 1$)$.

Table 1. Data regarding the number of Oral Health Teams, Oral Health Coverage in Primary Care, number of First Programmatic Dental Consultations, and number of visits due to dental abscess and toothache regarding all Brazilian states, from January to April 2019 and 2020.

\begin{tabular}{|c|c|c|c|c|c|}
\hline Variables & $\begin{array}{l}\text { January to } \\
\text { April } 2019\end{array}$ & $\begin{array}{l}\text { January to } \\
\text { April } 2020\end{array}$ & $\begin{array}{c}\text { Average Percentage } \\
\text { of variation between } \\
2020-2019\end{array}$ & $\begin{array}{c}\text { Median of the } \\
\text { Difference between } \\
2020-2019\end{array}$ & p-value \\
\hline Number of OHT & 28,018 & 29,662 & $6.13 \%$ & 45 & $<0.001$ \\
\hline $\mathrm{OHC}$ & $52.59 \%$ & $53.40 \%$ & $1.62 \%$ & 1.01 & 0.035 \\
\hline FPDC & $4,081,355$ & $2,437,646$ & $-38.70 \%$ & -42.806 & $<0.001$ \\
\hline Dental Abscess & 138,549 & 92,197 & $-29.04 \%$ & -1.032 & 0.002 \\
\hline Toothache & $1,846,995$ & $1,177,208$ & $-32.68 \%$ & -14.445 & $<0.001$ \\
\hline
\end{tabular}

OHT: Oral Health Team; OHC: Oral Health Coverage in Primary Care; FPDC: First Programmatic Dental Consultations. Differences were detected by the average percentage of variation, median of difference and statistical comparison (Wilcoxon test).

\section{Discussion}

Considering the high risk of contagion of COVID-19 in dental offices, there was a recommendation throughout the country for the elective care to be suspended, giving priority only to those considered urgency and emergency [14,15]. However, the present study showed a reduction in the number of visits due to dental abscesses and toothache, considered of urgency and emergency. In addition, there was a reduction in the 
number of first programmatic dental consultations. Although the number of oral health teams and oral health coverage in Primary Care has increased during the same period, this study's findings show the first negative impacts of the pandemic on the offer and use of public oral healthcare services in Brazil.

It is necessary to consider that the COVID-19 pandemic has a direct impact on patients' behavior in the search for dental care. In view of the recommendations for social isolation, some individuals are concerned about leaving home to seek the service, resulting in a reduction in the number of visits and seeking only in cases of extreme necessity. In addition, the population lacks clarity about what would be a dental urgency and emergency situation, with pain being a frequently referred symptom [16]. A study conducted in China showed a $38 \%$ drop in the number of patients seen at dental emergency service, with a significant reduction in demand for non-urgent cases in the pandemic period [17].

In a recent pre-pandemic scenario, Brazil showed an increase in the number of OHT, although accompanied by a drop in the quantity of FPDC, between 2015 and 2017 [18]. A reduction in the OHC in Primary Care was also observed as of 2016 [19]. Factors such as political instability and freezing of investments in health provided by the advance of austerity policies have had a negative impact on access to oral health care in recent years [19,20]. These effects, when added to the impacts of the pandemic, result in a worrying panorama. The frequency of FPDC four months of COVID-19 pandemic was similar to that observed during one month 2003, when the number of OHT was seven times lower.

The need to adapt to new dental care routines, as well as the high costs of personal protective equipment, can impact the reduction in the number of dental care procedures [21,22]. Thus, even in the face of a still rising contamination curve in Brazil, it is possible to suggest that oral health care will face thoughtful challenges during and after the COVID-19 pandemic. Although the main focus is given to the hospital environment during this period, the strengthening of primary care as a whole is essential to face these implications [11].

The results of this investigation indicate that the expansion of the assistance network has not yet been affected by the pandemic. Although oral health coverage is still far from reaching the entire Brazilian population, it is known that the public health system serves the majority of the most vulnerable population [10,23]. Therefore, setbacks in the expansion of the Brazilian National Health System dental care could contribute to an increase in oral health inequities [11,19].

The reduction in the number of first programmatic dental consultations would be expected once health services were advised to only assist to urgent and emergency demands [14]. However, this study's data point out the assistance to dental abscess and toothache cases reduced significantly during the first four months of the COVID-19 pandemic in Brazil. These indicators do not mean that dental urgency and emergency cases did not exist, but it is suggested that the public health sector did not assist such cases.

It is necessary for health services to prepare themselves adequately for returning elective care and effective resolution of dental urgency/emergency cases. The increase in restrained demand in oral health can represent a serious setback for the country's oral health epidemiological scenario. Tools such as telemedicine could be used by professionals in the healthcare network to provide access to information and guidance by a health professional, without disrespecting social isolation [24]. In addition to the purchase materials and equipment, it is also necessary to adapt some health centers' infrastructure. In this sense, greater government 
investments in the health area are needed to enable dental care continuity within the Brazilian National Health System.

This study has limitations regarding the use of secondary data, obtained from a health information system. It is necessary to consider the limitation of human resources during this period, which may impact on the lack of data registration. Thus, the drop in dental care verified in this study may actually mean the absence of records. Although the quality of registration may influence these data, it must be recognized that they are official information from the Ministry of Health of Brazil. Future investigations should consider a longer period of analysis, which makes it possible to verify the fluctuation of the indicators in the periods before, during and after the pandemic. The results of this study should be used by health managers and professionals to adapt the dental care provision routines, as well as by the population in general, which must demand the continued expansion of dental care within the Unified Health System.

\section{Conclusion}

Although there was an expansion of OHT and OHC between 2019 and 2020, the offer and use of oral health services in primary care was reduced due to the COVID-19 pandemic in Brazil. This phenomenon is likely to impact negatively the epidemiological data of oral health in Brazil.

\section{Authors' Contributions}

EHGL (D) 0000-0003-3431-115X Conceptualization, Methodology, Formal Analysis and Writing - Review and Editing. ARF (ID) 0000-0002-8082-5883 Investigation and Writing - Original Draft Preparation.

DEWF (D) 0000-0002-0001-7430 Investigation and Writing - Original Draft Preparation.

ECFA (D) 0000-0002-8303-8914 Investigation and Writing-Original Draft Preparation.

GNWL(D) 0000-0002-2685-8166 Investigation and Writing - Original Draft Preparation.

ACMB (D) 0000-000 1-5482-9592 Investigation and Writing - Original Draft Preparation.

WWP (D) 0000-0003-3056-9145 Conceptualization, Methodology, Formal Analysis and Writing - Review and Editing. YWC (D) 0000-0002-3570-9904 Conceptualization, Methodology, Formal Analysis and Writing - Review and Editing. All authors declare that they contributed to critical review of intellectual content and approval of the final version to be published.

\section{Financial Support}

None.

\section{Conflict of Interest}

The authors declare no conflicts of interest.

\section{References}

[1] Al-Jabir A, Kerwan A, Nicola M, Alsafi Z, Khan M, Sohrabi C, et al. Impact of the Coronavirus (COVID-19) pandemic on surgical practice - Part 1. Int J Surg 2020; 79:168-79. https://doi.org/10.1016/j.ijsu.2020.05.022

[2] Epidemiology Working Group for NCIP Epidemic Response, Chinese Center for Disease Control and Prevention. Zhonghua Liu Xing Bing Xue Za Zhi 2020; 41(2):145-51. https://doi.org/10.3760/cma.j.issn.0254-6450.2020.02.003

[3] Rothan HA, Byrareddy SN. The epidemiology and pathogenesis of coronavirus disease (COVID-19) outbreak. J Autoimmun 2020; 109:102433. https://doi.org/10.1016/j.jaut.2020.102433

[4] Brasil. Ministério da Saúde. Ministério da Saúde declara transmissão comunitária nacional. 2020a. Available from: $<$ https://www.saude.gov.br/noticias/agenciasaude/46568-ministerio-da-saude-declara-transmissao-comunitarianacional $>$. [Accessed on May 16, 2020]. [In Portuguese]

[5] Croda JHR, Garcia LP. Immediate health surveillance response to COVID-19 Epidemic. Epidemiol Serv Saude 2020; 29(1):e2020002. https://doi.org/10.5123/S1679-4974202000010002 1 
[6] Rodriguez-Morales AJ, Gallego V, Escalera-Antezana JP, Méndez CA, Zambrano LI, Franco-Paredes C, et al. COVID-19 in Latin America: The implications of the first confirmed case in Brazil. Travel Med Infect Dis 2020; 35:101613. https://doi.org/10.1016/j.tmaid.2020.101613

[7] Schuchmann AZ, Schnorrenberger BL, Chiquetti ME, Gaiki RS, Raimann BW, Maeyama MA. Vertical social isolation X Horizontal social isolation: health and social dilemas in copping with the COVID-19 pandemic. Braz J Health Rev 2020; 3(2):3556-76. https://doi.org/10.34119/bjhrv3n2-185

[8] Wilder-Smith A, Freedman DO. Isolation, quarantine, social distancing and community containment: pivotal role for old-style public health measures in the novel coronavirus (2019-nCoV) outbreak. J Travel Med 2020; 27(2):taaa020. https://doi.org/10.1093/jtm/taaa020

[9] Wilder-Smith A, Chiew CJ, Lee VJ. Can we contain the COVID-19 outbreak with the same measures as for SARS? Lancet Infect Dis 2020; 20(5):e102-e107. https://doi.org/10.1016/S1473-3099(20)30129-8

[10] Ribeiro F, Leist A. Who is going to pay the price of Covid-19? Reflections about an unequal Brazil. Int J Equity Health 2020; 19(1):91. https://doi.org/10.1186/s12939-020-01207-2

[11] Souza CDF, Gois-Santos VT, Correia DS, Martins-Filho PR, Santos VS. The need to strengthen Primary Health Care in Brazil in the context of the COVID-19 pandemic. Braz Oral Res 2020; 34:e047. https://doi.org/10.1590/1807-3107bor-2020.vol34.0047

[12] Brasil. Ministério da Saúde. Secretaria de Atenção Primária à Saúde. Nota Técnica No 16/2020CGSB/DESF/SAPS/MS. COVID-19 e o Atendimento Odontológico no SUS. Brasília: DF, 2020b. Available from: http://www.crosp.org.br/uploads/arquivo/ab69d79b87d04780afo8a70d8cee9d70.pdf. [Accessed on June 16, 2020]. [In Portuguese]

[13] Brasil. Ministério da Saúde. e-SUS Atenção Básica: Manual Sistema com Coleta de Dados Simplificada: CDS. Brasília, DF, 2013. Available from: http://189.28.128.100/dab/docs/portaldab/documentos/manual_CDS_ESUS_1_3_0.pdf. [Accessed on June 17, 2020]. [In Portuguese]

[14] Brasil. Agência Nacional de Vigilância Sanitária. Nota Técnica GVIMS/GGTES/ANVISA No 04/2020, de 08 de maio de 2020. Brasília: DF, $2020 . \quad$ Available from: http://portal.anvisa.gov.br/documents/33852/271858/Nota+T\%C3\%A9cnica+n+04-2020+GVIMS-GGTESANVISA/ab598660-3de4-4f14-8e6f-b9341c196b28>. [Accessed on June 16, 2020]. [In Portuguese]

[15] Conselho Federal de Odontologia. Recomendações AMIB/CFO para enfrentamento da COVID-19 na Odontologia. Brasília: DF, 2020. Available from: http://website.cfo.org.br/wp-content/uploads/2020/03/AMIB_CFORecomendac\%CC\%A7o\%CC\%83es.pdf. [Accessed on June 16, 2020]. [In Portuguese]

[16] Macek MD, Cohen LA, Reid BC, Manski RJ. Dental visits among older U.S. adults, 1999: the roles of dentition status and cost. J Am Dent Assoc 2004; 135(8):1 154-65. https://doi.org/10.14219/jada.archive.2004.0375

[17] Guo H, Zhou Y, Liu X, Tan J. The impact of the COVID-19 epidemic on the utilization of emergency dental services. J Dent Sci 2020. https://doi.org/10.1016/j.jds.2020.02.002

[18] Chaves SC, Almeida AM, Reis CS, Rossi TR, Barros SG. Oral Health Policy in Brazil: transformations in the period 2015-2017. Saúde Debate 2018; 42(2):76-91. https://doi.org/10.1590/0103-11042018S206

[19] Rossi TRA, Lorena Sobrinho JE, Chaves SCL, Martelli PJL. Economic crisis, austerity and its effects on the financing of oral health and access to public and private services. Cien Saude Coletiva 2019; 24(12):4427-36. https://doi.org/10.1590/1413-812320182412.25582019

[20] Melo EA, Mendonça MH, Oliveira JR, Andrade GC. Mudanças na Política Nacional de Atenção Básica: entre retrocessos e desafios. Saúde Debate 2018; 42(spe 1):38-51. https://doi.org/10.1590/0103-1 1042018s103

[21] Meng L, Hua F, Bian Z. Coronavirus Disease 2019 (COVID-19): Emerging and future challenges for dental and oral medicine. J Dent Res 2020; 99(5):481-7. https://doi.org/10.1177/0022034520914246

[22] Ge ZY, Yang LM, Xia JJ, Fu XH, Zhang YZ. Possible aerosol transmission of COVID-19 and special precautions in dentistry. J Zhejiang Univ Sci B 2020; 21(5):361-8. https://doi.org/10.1631/jzus.B2010010

[23] Bastos LF, Hugo FN, Hilgert JB, Cardozo DD, Bulgarelli AF, Santos CM. Access to dental services and oral healthrelated quality of life in the context of primary health care. Braz Oral Res 2019; 33:e018. https://doi.org/10.1590/1807-3107bor-2019.vol33.0018

[24] Caetano R, Silva AB, Guedes ACCM, Paiva CCN, Ribeiro GR, Santos DL, et al. Challenges and opportunities for telehealth during the COVID-19 pandemic: ideas on spaces and initiatives in the Brazilian context. Cad Saúde Pública 2020; 36(5): e00088920. https://doi.org/10.1590/0102-311x00088920 